\title{
THE WTO LEGAL SYSTEM: SOURCES OF LAW
}

\author{
By David Palmeter and Petros C. Mavroidis*
}

\section{INTRODUCTION}

Modern discussions of the sources of international law usually begin with a reference to Article 38(1) of the Statute of the International Court of Justice (ICJ), which provides:

The Court, whose function is to decide in accordance with international law such disputes as are submitted to it, shall apply:

a. international conventions, whether general or particular, establishing rules expressly recognized by the contesting states;

b. international custom as evidence of a general practice accepted as law;

c. the general principles of law recognized by civilized nations;

d. subject to the provisions of Article 59, judicial decisions and the teachings of the most highly qualified publicists of the various nations, as subsidiary means for the determination of rules of law. ${ }^{1}$

The Marrakesh Agreement Establishing the World Trade Organization (WTO Agreement) is a "particular" international convention within the meaning of Article 38(1) (a), as are a series of annexed additional agreements and legal instruments dealing with trade in goods and services as well as intellectual property rights. ${ }^{2}$ These are referred to as the "WTO Agreements" or "covered agreements." ing the substantive rights and obligations of members of the World Trade Organization under the covered agreements is governed by the Understanding on Rules and Procedures Governing the Settlement of Disputes (Dispute Settlement Understanding or DSU). ${ }^{4}$ In the words of Article 38(1) (a), the rules of the DSU "are expressly recognized by the contesting states" that are parties to WTO dispute settlement procedures.

The fundamental source of law in the WTO is therefore the texts of the relevant covered agreements themselves. All legal analysis begins there. In the words of the WTO Appellate Body, which was established by Article 17 of the DSU, "The proper interpretation of the Article is, first of all, a textual interpretation.",

\footnotetext{
* David Palmeter is a member of the firm Powell, Goldstein, Frazer \& Murphy LLP, Washington, D.C. Petros C. Mavroidis is Professor of Law, University of Neuchâtel, Switzerland. The authors would like to thank William J. Davey, Paul Demaret, Robert E. Howse, Ernst-Ulrich Petersmann, Yves Renouf and the Hon. Diane P. Wood for helpful comments on earlier drafts, and Natalie Erard for research assistance.

' See, e.g., Ian Brownlie, Principles of Public International Law 3 (4th ed. 1990); Barry E. Carter \& Phillip R. TRimble, International LaW 18 (2d ed. 1994); Rosalyn Higgins, Problems and Process: InTERnational Law and How We USe It 17-18 (1994); Malcolm N. Shaw, International Law 59 (1991). Article 59 of the Statute, referred to in Article 38(1)(d), provides simply: "The decision of the Court has no binding force except between the parties and in respect of that particular case."

${ }^{2}$ Agreement Establishing the World Trade Organization [hereinafter WTO Agreement], opened for signature Apr. 15, 1994, in Final Act Embodying the Results of the Uruguay Round of Multilateral Trade NEgOtIATIONS, MARRAKESH, 15 APRIL 1994 [hereinafter FinAl ACT], and 33 ILM 1144 (1994). For background on the WTO and the world trading system, see John H. JAckson, THE World Trading System (2d ed. 1997).

${ }^{3}$ The most important of these are the annex entitled "Multilateral Agreements on Trade in Goods," which includes the text of General Agreement on Tariffs and Trade 1994, with six Understandings concerning the interpretation of its articles, and 12 substantive agreements, running from the Agreement on Agriculture to the Agreement on Safeguards; the General Agreement on Trade in Services; and the Agreement on TradeRelated Aspects of Intellectual Property Rights.

${ }^{4}$ WTO Agreement, supra note 2, Understanding on Rules and Procedures Governing the Settlement of Disputes, 33 ILM at 1226 [hereinafter DSU].

${ }^{5}$ Japan-Taxes on Alcoholic Beverages, WTO Doc. AB-1996-2, WT/DS1/AB/R, WT/DS10/AB/R/, WT/ DS22/AB/4, at 19 (Nov. 1, 1996) [hereinafter Japan Alcohol AB Report].
} 
The texts, however, are only "first of all." They do not exhaust the sources of potentially relevant law. To the contrary, all of the subparagraphs of Article 38(1) are potential sources of law to be drawn on in WTO dispute settlement. More specifically, prior practice under the WTO's predecessor, the General Agreement on Tariffs and Trade (GATT), including reports of GATT dispute settlement panels; WTO practice, particularly reports of dispute settlement panels and the WTO Appellate Body; custom; the teachings of highly qualified publicists; general principles of law; and other international instruments - all contribute to the rapidly growing and increasingly important body of law known as "WTO law."

While there is no explicit equivalent to Article 38(1) in the Dispute Settlement Understanding or any other of the covered agreements, its terms are effectively brought into WTO dispute settlement by Articles 3.2 and 7 of the DSU. Article 3.2 specifies that the purpose of dispute settlement is to clarify the provisions of the WTO Agreements "in accordance with customary rules of interpretation of public international law." Article 7 specifies that the terms of reference for panels shall be " $[\mathrm{t}] \mathrm{o}$ examine, in the light of the relevant provisions in (. . . the covered agreement(s) cited by the parties to the dispute), the matter referred to the DSB" and to "address the relevant provisions in any covered agreement or agreements cited by the parties to the dispute."

The "DSB" is the Dispute Settlement Body, established by the DSU, with "the authority to establish panels, adopt panel and Appellate Body reports, maintain surveillance of implementation of rulings and recommendations, and authorize suspension of concessions and other obligations under the covered agreements."

This paper views Article 7 of the DSU as the WTO substitute, mutatis mutandis, for Article 38. From this perspective, it considers, as sources of law, the texts of the WTO Agreements; panel and Appellate Body reports interpreting "the relevant provisions" of those Agreements, as that term is used in Article 7; custom; the teachings of publicists; general principles of law; and other international instruments. It attempts to answer the question, What do the texts of the WTO Agreements and the WTO's adjudicating bodies consider to be the WTO sources of law?

\section{SOURCES OF LAW}

\section{Covered Agreements}

The term "covered agreements" in Article 7 of the Dispute Settlement Understanding means all of the multilateral WTO Agreements annexed to the Marrakesh WTO Agreement. In addition, the DSU is applicable to disputes between the parties to the two plurilateral agreements that are also part of the WTO. ${ }^{8}$ These texts, as noted, are the starting point for dispute settlement proceedings, since Article 6.2 of the DSU requires that a request for the establishment of a panel identify the legal basis for the request. The legal basis for a request would be the specific provisions of a particular agreement or agreements. Implicit in this requirement is a due process consideration of fair notice, which has led the Appellate Body to observe, " $[\mathrm{I}] \mathrm{t}$ is incumbent upon a panel to examine

\footnotetext{
${ }^{6}$ DSU, supra note 4, Art. 7 (emphasis added).

${ }^{7}$ Id., Art. 2.1.

${ }^{8}$ These are the Agreement on Civil Aircraft and the Agreement on Government Procurement. Two other plurilateral agreements, the International Dairy Agreement and the International Bovine Meat Agreement, were terminated at the end of 1997. Deletion of the International Dairy Agreement from Annex 4 of the WTO Agreement, Decision of Dec. 10, 1997, WTO Doc. WT/L/251 (Dec. 17, 1997); Deletion of the International Bovine Meat Agreement from Annex 4 of the WTO Agreement, Decision of Dec. 10, 1997, WTO Doc. WT/L/252 (Dec. 16, 1997).
} 
the request for the establishment of the panel very carefully to ensure its compliance with both the letter and the spirit of Article 6.2 of the DSU.",

The texts of several covered agreements explicitly refer to other international agreements, which, in this sense, may be considered to be "covered agreements." These are considered below in the section "Other International Instruments."

\section{Reports of Prior Panels and the Appellate Body}

Other than the texts of the WTO Agreements themselves, no source of law is as important in WTO dispute settlement as the reported decisions of prior dispute settlement panels. These include the reports of GATT panels as well as WTO panels, and now, of course, reports of the Appellate Body.

"Judicial decisions" are among the "subsidiary" sources of international law specified in Article 38(1) (d) of the Statute of the ICJ. Read together with Article 59 of the Statute, which confines the binding force of a decision of the Court to the parties, Article 38 (d) (1) has produced a system of precedent under which the Court essentially refers to and considers its prior decisions, but is not legally required to follow them. As Judge Mohamed Shahabuddeen has observed, however, "though having the power to depart from them, [the Court] will not lightly exercise that power." 10 The law of the WTO effectively duplicates this system.

Adopted and unadopted panel reports. The WTO Agreement specifies that the WTO shall be guided by the decisions, procedures and customary practices followed by the CONTRACTING PARTIES to GATT 1947 and the bodies established in the framework of GATT 1947. ${ }^{11}$ Implementing this requirement in the context of trade in goods, one of the most important of the WTO Agreements, GATT 1994, specifies that the Agreement includes, inter alia, "decisions of the CONTRACTING PARTIES to GATT 1947.",

The question whether adopted GATT panel reports represent "decisions" of the CONTRACTING PARTIES to GATT 1947 arose in Japan - Taxes on Alcoholic Beverages. ${ }^{13}$ Without referring explicitly to Article $38(1)$ (d) of the World Court Statute, the panel effectively treated adopted reports as if they had the status of judicial decisions. Specifically, it determined that adopted reports are an integral part of GATT 1994 since they are "other decisions of the Contracting PARTIES to GATT 1947" within the meaning of Article 1(b) (iv) of GATT 1994. ${ }^{14}$ The Appellate Body disagreed, but in the end it is difficult to detect any practical difference resulting from the disagreement, which may have been largely semantic. ${ }^{15}$

The Appellate Body held that a "decision" to adopt a panel report is not a "decision" within the meaning of Article 1(b) (iv). It did not say what adopted reports are if they are not "decisions," other than to say that they are "an important part of the GATT acquis." "16 This is somewhat confusing, both because the legal source of this acquis is not

\footnotetext{
${ }^{9}$ European Communities - Regime for the Importation, Sale and Distribution of Bananas, WTO Doc. AB1997-3, WT/DS27/AB/R, para. 142 (Sept. 9, 1997).

${ }^{10}$ Mohamed ShahabuddeEn, Precedent in the World Court 3 (1996).

${ }^{11}$ WTO Agreement, supra note 2, Art. XVI:1 (except as otherwise provided under the Agreement or the multilateral WTO Agreements).

12 "GATT 1947" is the term applied to the original GATT. The same text is incorporated in toto into the WTO as part of "GATT 1994." In GATT practice, the term "CONTRACTING PARTIES" referred to actions of all of the parties acting collectively; individual parties were referred to with initial capitals as "Contracting Parties." In referring to the provisions of GATT 1947 as they currently apply via GATT 1994, this paper uses the term "GATT." It uses "GATT 1994" for the entire GATT 1994 Agreement, including GATT

${ }^{13}$ WTO Doc. WT/DS8/R, WT/DS10/R, WT/DS11/R, adopted as modified by the Appellate Body (Nov. 1, 1996) [hereinafter Japan Alcohol-Panel Report].

${ }^{14} I d$., para. 6.10 .

${ }^{15}$ This discussion is based on section $\mathrm{E}$ of the Appellate Body's report, Japan Alcohol-AB Report, supra note 5, at 13 (text of Oct. 4, 1996)

${ }^{16}$ See id. at 15 .
} 
specified and because, in its discussion of the issue, the Appellate Body itself refers to "a decision" and "decisions" to adopt panel reports. ${ }^{17}$

The Appellate Body apparently was concerned that the panel's conclusion could be interpreted as holding that adopted reports "constitute a definitive interpretation of the relevant provisions of GATT 1947." "A "definitive interpretation" would presumably be controlling and thus, on this theory, could amount to importation of rigid stare decisis into the WTO, if not amendment sub rosa of its very texts. If this was the concern, it seems misplaced. The panel treated adopted reports as "subsidiary" sources of WTO law, comparable in status to judicial decisions in the World Court. It did not say that adopted reports were controlling. Rather, it said that they "have to be taken into account by subsequent panels dealing with the same or a similar issue." ${ }^{19}$ It specified, however, that "it does not necessarily have to follow their reasoning or results." 20 Thus, in the panel's view, an adopted report does not "constitute a definitive interpretation" of an agreement; it is simply a "decision" that has to be considered-but not necessarily followed - by the panel. The panel effectively agreed with Judge Shahabuddeen's invocation of Shabtai Rosenne: "Precedents may be followed or discarded, but not disregarded.,"21

In its description of adopted reports, the Appellate Body came very close to saying the same thing: "[Adopted reports] are often considered by subsequent panels. They create legitimate expectations among WTO Members, and, therefore, should be taken into account where they are relevant to any dispute. However, they are not binding, except with respect to resolving the particular dispute between the parties to that dispute.",22

This statement reads very much like Article $38(1)(\mathrm{d})$ of the Statute of the ICJ and its reference to "subsidiary" sources of international law. Indeed, in a footnote to this passage, the Appellate Body went on to draw a parallel to the practice of the World Court:

It is worth noting that the Statute of the International Court of Justice has an explicit provision, Article 59, to the same effect. This has not inhibited the development by that Court (and its predecessor) of a body of case law in which considerable reliance on the value of previous decisions is readily discernible. ${ }^{23}$

All of this discussion took place in the context of GATT reports. However, the same reasoning, mutatis mutandis, would apply to adopted WTO reports themselves, not only those concerned with GATT 1994, but also those concerned with the General Agreement on Trade in Services, the Agreement on Trade-Related Aspects of Intellectual Property Rights, and the plurilateral trade agreements. In the end, the result seems to be that adopted reports are not binding precedent and do not control subsequent panels; neither may they "add to or diminish the rights and obligations provided in the covered agreements." ${ }^{24}$ Nevertheless, panels "should" take them into account. Adopted reports have strong persuasive power and may be viewed as a form of nonbinding precedent, whose role is comparable to that played by la jurisprudence in the contemporary civil law of many countries, such as France, and that played by decisions of courts at the same level in the United States. As a practical matter, parties will continue to cite prior reports to panels, and panels will continue to take them into account by adopting

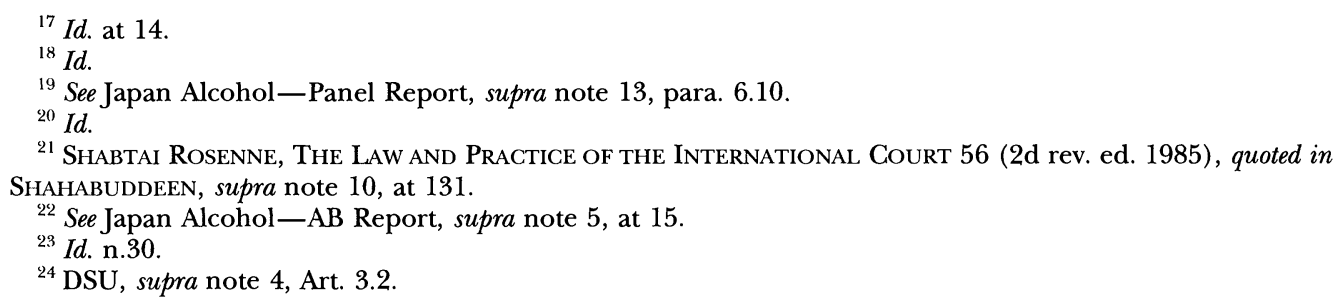


their reasoning - in effect, following precedent - unless panels conclude, for good and articulated reasons, that they should do otherwise.

The role of unadopted panel reports is somewhat less, but they remain relevant. The Appellate Body agreed with the panel in Japan-Alcoholic Beverages that unadopted reports "have no legal status in either the GATT or the WTO system since they have not been endorsed through decisions by the ConTracting PARTIEs to GATT or WTO Members." ${ }^{25}$ However, the Appellate Body also agreed with the panel that "a panel could nevertheless find useful guidance in the reasoning of an unadopted panel report that it considered to be relevant." 26

The persuasive power of the prior reports rests not only on the reasoning they contain, important as this is, but also on the mere fact that once a dispute has been decided a certain way, subsequent panels are likely to follow even if they believe they might have decided the case otherwise had they been viewing the question in the first instance. Continuity and consistency are valuable attributes in any legal system: application of the same rules to the same factual issues, regardless of the parties involved-treating like cases alike - is an important source of legitimacy for any adjudicator. It is particularly important for international adjudicators, who, unlike their municipal counterparts, lack a monopoly of enforcement power, and have only the power to persuade the addressees of their decisions that those decisions are correct. ${ }^{27}$ Thus, if a panel decides not to treat like cases alike by not following a prior report, the panel most certainly "should" - to use the words of the Appellate Body-address that report, which "create[d] legitimate expectations among WTO Members." To do otherwise would call into serious question the very legitimacy of the process.

Tribunals choose to follow previous cases not only for reasons of fairness and legitimacy, but also for reasons of efficiency: today's tribunal benefits from the work done yesterday on the same legal question; the wheel does not have to be reinvented. Finally, following precedent tends to make the law clearer and more certain, which is also of benefit to the legal system and those that take part in it.

The practical impact of the status of prior panel reports as persuasive but not binding is to put the burden on the party seeking a different interpretation to show the panel why it should depart from the reasoning and conclusions of its predecessor. Because, as the Appellate Body has said, adopted reports "create legitimate expectations," persuading a panel to depart from precedent can - and should - be difficult. It is not impossible, however, as can be seen from the statement of a panel declining to follow a previous panel in nearly identical circumstances, which is worth quoting at length:

In considering the facts and arguments relating to Article XI in particular, the Panel took note of the fact that a previous Panel, in 1980, had reported on a complaint involving the same product and the same parties as the present matter and a similar set of GATT issues. The Panel noted carefully the arguments of the parties concerning the precedent value of this Panel's and other previous panels' recommendations, and the arguments on the legitimate expectations of contracting parties arising out of the adoption of panel reports. The Panel construed its terms of reference to mean that it was authorized to examine the matter referred to it by Chile in the light of all relevant provisions of the General Agreement and those related to its interpretation and implementation. It would take into account the 1980 Panel report and the legitimate expectations created by the adoption of this report, but also other GATT practices and panel reports adopted by the CONTRACTING PARTIES and

\footnotetext{
${ }^{25}$ Japan Alcohol-AB Report, supra note 5, at 15 (quoting Japan Alcohol-Panel Report, supra note 13, para. 6.10)

${ }^{26} I d$. at 16 (quoting Japan Alcohol-Panel Report, para. 6.10).

${ }^{27}$ See Thomas M. Franck, Fairness in International LAw AND InStitutions 26-46 (1995).
} 
the particular circumstances of this complaint. The Panel, therefore, did not feel it was legally bound by all the details and legal reasoning of the 1980 Panel report. ${ }^{28}$

The WTO panel in Japan-Alcoholic Beverages itself declined to follow the reasoning in two prior panels, one unadopted, the other adopted. As to the unadopted report, the panel said that it "was not persuaded by the reasoning," and, as to the adopted report, that it had "decided not to follow the interpretation of the term 'like product' as it appears in Article III:2, first sentence, advanced by the 1992 Malt Beverages report in so far as it incorporates the aim-and-effect test," which it had previously discussed at length and dismissed. ${ }^{29}$

Each of these panels stated why it had decided not to follow the previously adopted reports. It is precisely this need to justify departures from prior cases that is key for an international adjudicating body in its quest for legitimacy. Sir Gerald Fitzmaurice expressed a similar view with respect to the functioning of the World Court:

It would seem that, although the Court is not obliged to decide . . . on the basis of previous decisions as such, what it can do is to take them fully into account in arriving at subsequent decisions, and that . . . it is mandatory for it to apply judicial decisions in the sense of employing them as part of the process whereby it arrives at its legal conclusions in the case. ${ }^{30}$

No doubt in part because prior panel reports are not legally binding, and perhaps in part because of GATT's diplomatic heritage, parties and panels use peculiar language in referring to earlier decisions. They "note" prior reports; ${ }^{31}$ they "recall" them. ${ }^{32}$ They "concur" with the reasoning of the prior panel. ${ }^{33}$ In one of the early WTO panel reports, the panel quoted another report at length and said, "We see great force in this argument." Whatever word or words they use, however, panels are likely to "follow" the reports of previous panels unless those reports can be distinguished from the cases before them or the panels can be convinced that the previous panels were in error. ${ }^{35}$

Nevertheless, panels can sometimes seem to be trains passing in the night, as indicated by two reports arising out of the Agreement on Textiles and Clothing that were faced at the outset with the question of the appropriate standard of review. The first panel, Cotton and Man-Made Fibre Underwear, in a report dated November 8, 1996, found "great force" in the argument of a 1985 panel. ${ }^{36}$ Two months later, the second panel, Woven

\footnotetext{
${ }^{28}$ European Economic Community-Restrictions on Imports of Dessert Apples, Complaint by Chile, June 22, 1989, GATT B.I.S.D. (36th Supp.) at 93, 123-24, para. 12.1 (1990) (citation omitted).

${ }^{29}$ See Japan Alcohol-Panel Report, supra note 13, para. 6.18.

${ }^{30}$ See Gerald Fitzmaurice, The Law and Procedure of the International Court of Justice 584 (1986).

${ }^{31}$ See Japan Alcohol-Panel Report, supra note 13, para. 6.11; United States-Standards for Reformulated and Conventional Gasoline, WTO Doc. WT/DS2/R, adopted as modified by the Appellate Body, para. 6.11 (May 20, 1996), 35 ILM 274 (1996) [hereinafter U.S. Gasoline-Panel Report].

${ }^{32}$ U.S. Gasoline-Panel Report, supra note 31, paras. 6.10, 6.40; Japan Alcohol-Panel Report, supra note 13, para. 6.19 .

${ }_{33}^{33}$ U.S. Gasoline-Panel Report, supra note 31, para. 6.14.

${ }^{34}$ United States - Restrictions on Imports of Cotton and Man-Made Fibre Underwear, WTO Doc. WT/ DS24/R, adopted as modified by the Appellate Body, para. 7.12 (Feb. 25, 1997) [hereinafter U.S. CottonPanel Report] (referring to New Zealand-Imports of Electrical Transformers from Finland, July 18, 1985, GATT B.I.S.D. (32d Supp.) at 55 (1986)).

${ }^{35}$ This language suggests that the drafters of these reports were aware of comparable language in reports of the Permanent Court of International Justice. See SHAHABuddeEn, supra note 10, at 17. The phraseology continues in the World Court, as evidenced by the recent case Gabčíkovo-Nagymaros Project (Hung. v. Slovk.), 1997 ICJ REP. 92 (Sept. 25): "The Court recalls that it has recently had occasion to stress . . ." (para. 53); "The Court recalls that, in the Fisheries Jurisdiction case . . ." (para. 104); "The Court will recall in this context that, as it said in the North Sea Continental Shelf cases . . ." (para. 141); but more authoritatively, "The Permanent Court of International Justice stated in its Judgment of 13 September 1928 in the case concerning the Factory at Chorzów . . ." (para. 149) (emphasis added).

${ }^{36}$ U.S. Cotton-Panel Report, supra note 34, paras. 7.11-12.
} 
Wool Shirts and Blouses, in a report dated January 6, 1997, dismissed the 1985 report together with other reports cited by the parties:

We do not consider that the reports cited by the parties are relevant to the present dispute. . . . [They] were adopted many years ago . . . and they interpreted different agreements in different contexts. . . . [T] he ATC has instituted a new regime for textile products and the DSU has instituted new rules for panels. ${ }^{37}$

The panel in Woven Wool Shirts and Blouses not only saw the prior reports very differently; it did not even refer to the panel report in Cotton and Man-Made Fibre Underwear and its consideration of the same question. Given the sizable records in both cases, the fact that the nearly contemporaneous proceedings overlapped to a considerable degree and the time constraints on panels, this result is not surprising. It is more than likely that the panel in Woven Wool Shirts and Blouses was not even aware of the report on Cotton and Man-Made Fibre Underwear at the time it prepared its own report.

Finally, the question of the degree to which facts found by a previous panel may be relevant to a later panel has not arisen often. Nevertheless, one of the early WTO panels had occasion to consider the purely factual conclusion of an earlier GATT panel. After quoting the previous panel's factual finding, the WTO panel said, "Following its independent consideration of the factors mentioned in the 1987 Panel Report, the Panel agreed with this statement." 38 It went on to observe that the responding member had "offered no further convincing evidence that the conclusion reached by the 1987 Panel Report was wrong," thus clearly stating the otherwise always implicit burden on the party challenging a prior report, as to law or fact, to demonstrate its error. ${ }^{39}$

Appellate Body reports. As a formal matter, Appellate Body reports, like panel reports, bind only the parties to the particular dispute, and do not create binding precedent. The text of any agreement is open to reinterpretation regardless of what a panel or the Appellate Body has said about it, by virtue of the last sentence of Article 3.2 of the DSU, which provides: "Recommendations and rulings of the DSB cannot add to or diminish the rights and obligations provided in the covered agreements." If the recommendations and rulings of the DSB-which has the authority to adopt or reject reports of panels or the Appellate Body-cannot add to or diminish the rights of members under the agreements, a fortiori those of panels or the Appellate Body cannot.

This having been said, however, it is clear that not very much has been said. The DSB cannot refuse to adopt a report absent consensus, and consensus requires at a minimum that the prevailing party not object. ${ }^{40}$ Rarely will a party join in opposing the adoption of a report in its favor. The real question, therefore, is the extent to which panels and the Appellate Body itself will treat Appellate Body reports as authoritative.

The answers to these questions must await more experience; however, it is reasonable to presume that, absent unusual circumstances, panels will follow the decisions of the Appellate Body in much the same way that a lower court follows the decisions of a higher court. This is a mandatory practice in some legal systems. In others it occurs as a practical matter. ${ }^{41}$

In one of the early instances, a panel referred to an Appellate Body report in language reminiscent of that used by panels in "recalling" and referring affirmatively to other panel reports: "The Panel recalled in this respect the conclusions of the Appellate Body

\footnotetext{
${ }^{37}$ United States-Measure Affecting Imports of Woven Wool Shirts and Blouses from India, WTO Doc. WT/DS33/R, para. 7.15 ( Jan. 6, 1997).

${ }^{38} \mathrm{Japan}$ Alcohol-Panel Report, supra note 13, para. 6.23.

${ }^{39} I d$.

${ }^{40} \mathrm{DSU}$, supra note 4, Art. 16.

${ }^{41}$ See, e.g., RenÉ David, French Law: Its Structure, Sources, And Methodology 186 (Michael Kindred trans., 1972).
} 
in its report on United States-Standards for Reformulated and Conventional Gasoline where it stated that 'an interpreter is not free to adopt a reading that would result in reducing whole clauses or paragraphs of a treaty to redundancy or inutility. ", 42 The panel in Woven Wool Shirts and Blouses, on the other hand, adopted a slightly more deferential tone toward reports of the Appellate Body, suggestive of the way that panels are likely to view those reports in practice: "[W]e note that the Appellate Body has made clear . . . . The Appellate Body also concluded that . . . ."43

The panel's stating that with regard to one point the Appellate Body "made clear," and that with regard to another point it "concluded," is at least suggestive of a tendency to treat Appellate Body reports as controlling the decisions of panels in subsequent cases. Thus, it seems more likely that, rather than explicitly declining to follow a decision of the Appellate Body, a panel would attempt to distinguish the case before it.

The Appellate Body is likely to be even more prone than panels to follow its own prior decisions. This is because the Appellate Body is effectively a standing judicial body, while panels are not. Panels are chosen ad hoc from a roster of individuals whose names have been put forward by WTO members. ${ }^{44}$ They are generally present or former members of nonparty Geneva delegations to the WTO, or academics-law professors and economists. ${ }^{45}$ Those sitting on a particular panel have probably never served together before, and are likely never to serve together again, although a number of persons have served on several panels. ${ }^{46}$

The Appellate Body, by contrast, operates on a "collegial" basis. While only three of the seven members sit on any one "division" to hear a particular appeal, and that division retains full authority to decide the case,${ }^{47}$ views on the issues are shared with the other Appellate Body members before a decision is reached. ${ }^{48}$ Consequently, members of the Appellate Body, in confronting prior decisions, are far more likely to be confronting their own decisions, or those of their close colleagues, than are WTO panelists. This relationship seems likely to lead to a stronger attachment to the reasoning and results of those decisions. "Once standing judicial bodies have come into existence," Judge Shahabuddeen has observed, "they provide an additional mechanism for the further development of the law." 49

An early example appears in the Appellate Body's second opinion, Japan-Alcoholic Beverages, where it made two references to its first opinion, United States-Standards for Reformulated and Conventional Gasoline, dealing with treaty interpretation:

(1) “[I]n United States-Standards for Reformulated and Conventional Gasoline, we stressed the need to achieve such clarification by reference to the fundamental rule of treaty interpretation set out in Article 31(1) of the Vienna Convention",;0 and

\footnotetext{
${ }^{42}$ Japan Alcohol-Panel Report, supra note 13, para. 6.22.

${ }^{43}$ See United States-Measure Affecting Imports of Woven Wool Shirts and Blouses from India, supra note 37, para. 7.15 .

${ }_{44}$ DSU, supra note 4, Art. 8.4.

${ }^{45}$ Panels are normally composed of three individuals, with one serving as chair. The parties may agree, however, to a five-member panel provided they do so within 10 days of the establishment of the panel by the DSB. Id., Art. 8.5.

${ }^{46}$ Switzerland, Australia, New Zealand and Hong Kong were the leaders in providing panelists for the first 10 WTO panels to issue reports. This probably reflects the fact that, as seen by other WTO members, these members have a relatively large pool of qualified individuals and are not from a major user of the dispute settlement system. No Americans and only one Japanese served on these first 10 panels.

${ }^{47}$ See DSU, supra note 4, Art. 17.1.

${ }^{48}$ Appellate Body, Working Procedures for Appellate Review, as amended, WTO Doc. WT/AB/WP/3, Rule 4 (Feb. 28, 1997).

${ }^{49}$ SHAHABUDDEEN, supra note 10 , at 45 .

${ }^{50}$ See Japan Alcohol-AB Report, supra note 5, at 10-11 (emphasis added).
} 
(2) “In United States-Standards for Reformulated and Conventional Gasoline, we noted that ...., 51

While the words "we stressed" and "we noted" are not the same, in a legal context, as "we held," there is an authoritative tone to them that suggests more than mere persuasion. The tone suggests that, in the view of the Appellate Body, those issues are closed.

The extent to which the Appellate Body should depart from its prior decisions presents it with something of a dilemma. On the one hand, stability in the law-and treating like cases alike - is served by declining to depart from prior decisions, even those which, in retrospect, may seem ill-advised, leaving it to the members to change the text of an agreement should they believe the Appellate Body to be wrong. On the other hand, the virtual automaticity with which reports of the Appellate Body will be adopted, and the fact that negotiations leading to changes in text are so infrequent and so difficult, mean that there is no practical way members can easily change the texts of a covered agreement - and thereby change the law-if they disagree with the Appellate Body. Therefore, the likelihood that its rulings will be the final word on the subject should arguably lead the Appellate Body to a greater willingness to reexamine them, for finality does not equate with infallibility. The Appellate Body, in substance if not in form, is a court of last resort, and "courts of last resort have come to accept that they are not obliged to follow their previous decisions; within careful bounds, they may depart.",52

\section{Custom}

Customary international law plays a specific role in WTO dispute settlement by virtue of Article 3.2 of the Dispute Settlement Understanding, which specifies that the purpose of dispute settlement is to clarify the provisions of the WTO Agreements "in accordance with customary rules of interpretation of public international law." In practice, Article 3.2 has led panels and the Appellate Body to Articles 31 and 32 of the Vienna Convention on the Law of Treaties, which have been held to codify customary international law on the subject. ${ }^{53}$ These customary rules of interpretation are, so far, the only portions of customary international law to have found their way meaningfully into WTO dispute settlement.

The issue of custom did arise in one important WTO proceeding. This was the question whether the precautionary principle is part of customary international law. ${ }^{54}$ In $E C$ Measures Concerning Meat and Meat Products (Hormones), the panel stated that "even if" the precautionary principle is considered customary international law, it would not override explicit provisions of the WTO Agreements. ${ }^{55}$ This conclusion was affirmed

\footnotetext{
${ }^{51} I d$. at 12 (emphasis added).

${ }^{52}$ ShahabuddeEN, supra note 10, at 238. The words of former U.S. Supreme Court Associate Justice Robert H. Jackson are relevant:
}

Whenever decisions of one court are reviewed by another, a percentage of them are reversed. That reflects a difference in outlook normally found between personnel comprising different courts. However, reversal by a higher court is not proof that justice is thereby better done. . . . We are not final because we are infallible, but we are infallible only because we are final.

Brown v. Allen, 344 U.S. 443, 540 (1953) (Jackson, J., concurring).

${ }^{53}$ See, e.g., United States-Standards for Reformulated and Conventional Gasoline, WTO Doc. AB-19961, WT/DS2/AB/R, at 17 (May 20, 1996), 35 ILM 603 (1996). For the Vienna Convention on the Law of Treaties, opened for signature May 23, 1969, see 1155 UNTS 331.

${ }^{54}$ The "precautionary principle" holds generally that, " $[\mathrm{w}]$ here there are threats of serious or irreversible damage, lack of full scientific certainty shall not be used as a reason for postponing cost-effective measure to prevent environmental degradation." Rio Declaration on Environment and Development, June 14, 1992, Principle 15, 31 ILM 874, 879 (1992). See also Franck, supra note 27, at 370; 1 Philippe SANDS, Principles of INTERNATIONAL ENVIRONMENTAL LAW 208-13 (1995).

${ }^{55}$ EC-Measures Concerning Meat and Meat Products (Hormones), Complaint by the United States, WTO Doc. WT/DS26/R/USA, para. 8.157 (Aug. 18, 1997), and Complaint by Canada, WTO Doc. WT/DS48/R/ CAN, para. 8.160 (Aug. 18, 1997). 
by the Appellate Body, which noted that the status of the precautionary principle in international law is the subject of debate. ${ }^{56}$ The Appellate Body also stated that, while the precautionary principle might have crystallized into a general principle of customary international environmental law, it is less than clear whether it has been widely accepted as a principle of general or customary international law. ${ }^{57}$ The opinion does not reveal what the consequences would be if, in the view of the Appellate Body, the principle had been accepted as part of customary international environmental law but not of international law generally.

But the WTO, like GATT before it, is grounded in agreement, not in custom, and questions of custom are therefore likely to be rare. Even GATT's first and most basic provision, the most-favored-nation clause (MFN), was not a codification of customary international law; nor did it establish a custom. To the contrary, GATT's MFN obligation extended only to other contracting parties, and contracting parties frequently denied MFN to nonparties, as the United States did, for example, with China. This remains true for the WTO Agreements.

Article XVI:1 of the WTO Agreement, as stated earlier, specifies that "the WTO shall be guided by the decisions, procedures and customary practices followed by the Contracting PARTIEs to GATT 1947." It is doubtful that the "customary practices" referred to would be recognized as customary international law. Although the customary practices of GATT might meet some of the requirements of custom, it is doubtful that they were accepted by the parties to GATT or are viewed by the members of the WTO "as law." 58

\section{Teachings of the Most Highly Qualified Publicists}

Sporadic references can be found in panel reports to the teachings and writings of highly qualified publicists in GATT law, but these references are rare. ${ }^{59}$ In large part, this reluctance may stem from GATT's diplomatic heritage. What is now essentially a juridical system of dispute settlement began as a diplomatic system of "conciliation." Not only were diplomats less likely than lawyers to be aware of or to be influenced by the writings of legal scholars; GATT diplomats for many years were decidedly averse to the notion of turning "conciliation" into a legal proceeding. ${ }^{60}$ The views of legal publicists, however qualified, impressed few "old GATT hands.",61

If legal scholars are more likely than diplomats to cite the writings of other legal scholars, one of the reasons for the relative absence of scholarship thus far is the relative absence of scholars among the panelists. While some academics have served as panelists, particularly in recent years, for most of GATT's history the practice was not widespread. Indeed, some WTO members appear to think it undesirable if a potential panelist has expressed any views remotely related to the issue about to be adjudicated-a "paper trail" test that would exclude many scholars. While there are some notable exceptions, and some of these notable exceptions have actually served as panelists, the fact remains

\footnotetext{
${ }^{56}$ EC-Measures Concerning Meat and Meat Products (Hormones), WTO Doc. AB-1997-4, WT/DS26/ $\mathrm{AB} / \mathrm{R}, \mathrm{WT} / \mathrm{DS} 48 / \mathrm{AB} / \mathrm{R}$, para. 123 (Jan. 16, 1998).

${ }^{58}$ This is the opinio juris requirement, set out in Article $38(1)(b)$ of the Statute of the International Court of Justice.

${ }_{59}^{5}$ See, e.g., United States-Measures Affecting Alcoholic and Malt Beverages, June 19, 1992, GATT B.I.S.D. (39th Supp.) at 206, 285 (1993) (citing the works of Prof. John H. Jackson and Prof. Robert E. Hudec).

${ }^{60}$ The history is recounted in two volumes by Robert E. Hudec, THE GATT Legal System AND WorLd Trade Diplomacy (2d ed. 1990), and ENFORCING INTERnational Trade LaW: THE Evolution of the Modern GATT LEGAL SySTEM (1993).

${ }^{61}$ This skeptical attitude toward law is apparent from the very title of a work by GATT's second Director General. Olivier LONG, LAW AND Its Limitations In THE GATT Multilateral Trade SySTEM (1985) (emphasis added).
} 
that the names of some highly qualified publicists are not even on the roster of panelists (and it is member governments, after all, that establish the roster).

The authors of WTO reports, on the other hand, particularly members of the Appellate Body, seem to be far more willing than their GATT predecessors to refer to the teachings of highly qualified publicists in justifying their positions. ${ }^{62}$ This development no doubt reflects recognition of the increasing importance of law to the trading system, made clear by the very establishment of the Appellate Body. The Appellate Body, confined to considering issues of law and legal interpretations of panel reports, ${ }^{63}$ of necessity brings a legal perspective to the process; and panels, advised by lawyers (as was not the case for the first few decades of GATT), increasingly deal with complex issues of law, such as standing, adequacy of notice and admissibility of evidence.

\section{General Principles of Law}

On occasion GATT panels have invoked general principles of law in support of their reasoning, as have WTO panels and the Appellate Body. The principle that an exception to a general rule should be interpreted narrowly has been utilized several times. ${ }^{64}$ This principle, however, has been rejected by the Appellate Body, which effectively, and reasonably, has concluded that one portion of the text of an agreement is not superior or inferior to another, unless the text itself so indicates. ${ }^{65}$ In United States-Measures Affecting Imports of Softwood Lumber from Canada, the panel effectively invoked the equitable principle of estoppel in a proceeding involving subsidies and countervailing measures. ${ }^{66}$ The interpretive principle that readings which would result in reducing whole clauses or paragraphs of a text to "redundancy or inutility" must be avoided has been recognized several times by the Appellate Body. ${ }^{67}$

Articles 22.4 and 22.6 of the Dispute Settlement Understanding, confining the level of suspension of concessions to the level of the nullification and impairment, are, of course, more than principle. They are the law of the Agreement itself. It is worth noting, however, that these provisions conform to the principle of proportionality recognized by the World Court. ${ }^{68}$

\footnotetext{
${ }^{62}$ See, e.g., Argentina-Measures Affecting Imports of Footwear, Textiles, Apparel and Other Items, WTO Doc. WT/DS56/R, at nn.176 (John H. Jackson), 184 (Keith Highet), 185 (Mojtaba Kazazi) (Nov. 25, 1997); India-Patent Protection for Pharmaceutical and Agricultural Chemical Products, WTO Doc. AB-1997-5, WT/DS50/AB/R, at nn.26 (F. Roessler, E.-U. Petersmann), 28 (E.-U. Petersmann), 52 (I. Brownlie) (Dec. 19, 1997); EC-Measures Concerning Meat and Meat Products (Hormones), supra note 56, at n.92 (P. Sands, J. Cameron, J. Abouchar, P. Birnie, A. Boyle, L. Gündling, A. deMestral, D. Bodansky).

${ }^{63}$ DSU, supra note 4, Art. 17.6.

${ }^{64}$ U.S. Cotton-Panel Report, supra note 34, para. 7.21 (citing several additional cases). See also CanadaImport Restrictions on Ice Cream and Yoghurt, Dec. 5, 1989, GATT B.I.S.D. (36th Supp.) at 68, 84, para. 59 (1990). "The Panel recalled that . . . . exceptions were to be interpreted narrowly" (citing Japan-Restrictions on Imports of Certain Agricultural Products, Mar. 22, 1988, GATT B.I.S.D. (35th Supp.) at 163 (1989), and EECRestrictions on Imports of Apples, Complaint by the United States, June 22, 1989, id. (36th Supp.) at 135).

${ }^{65}$ EC-Measures Concerning Meat and Meat Products (Hormones), supra note 56, para. 104:
}

[M] erely characterizing a treaty provision as an "exception" does not by itself justify a "stricter" or "narrower" interpretation of that provision than would be warranted by examination of the ordinary meaning of the actual treaty words, viewed in context and in the light of the treaty's object and purpose, or, in other words, by applying the normal rules of treaty interpretation.

${ }^{66}$ United States-Measures Affecting Imports of Softwood Lumber from Canada, Oct. 27-28, 1993, GATT B.I.S.D. (40th Supp.) at 358, 480-86, paras. 308-25 (1994).

${ }^{67}$ U.S. Gasoline-Panel Report, supra note 31, sec. III.B, at 23; Japan Alcohol-Panel Report, supra note 13, para. 6.22; Japan Alcohol-AB Report, supra note 5, at 12; United States-Restrictions on Imports of Cotton and Man-Made Cotton Fibre Underwear, WTO Doc. AB-1996-3, WT/DS24/AB/R, at 16, adopted Feb. 25, 1997 (Feb. 10, 1997).

68 " [A] n important consideration is that the effects of a countermeasure must be commensurate with the injury suffered"; this is "the proportionality which is required by international law." Gabčíkovo-Nagymaros Project, 1997 ICJ REP. 92, para. 85. 


\section{Other International Instruments}

Other international instruments, or agreements, may become sources of WTO law either because they are referred to specifically in the covered agreements or because the parties to a WTO dispute are also parties to another agreement.

Agreements referred to in the WTO Agreements. The texts of several covered agreements explicitly refer to other international agreements, which may therefore serve as direct sources of law in WTO dispute settlement proceedings. These include the major international intellectual property conventions, the Paris Convention (1967), the Bern Convention (1971), the Rome Convention, and the Treaty on Intellectual Property in Respect of Integrated Circuits, as provided for by the Agreement on Trade-Related Aspects of Intellectual Property Rights (TRIPS) ${ }^{69}$ The WTO Agreement on Subsidies and Countervailing Measures provides, somewhat indirectly, that the grant by governments of export credits in conformity with the provisions of the Arrangement on Guidelines for Officially Supported Export Credits of the Organisation for Economic Co-operation and Development shall not be considered an export subsidy. ${ }^{70}$

As noted above, the reference in Article 3.2 of the DSU to the "customary rules of interpretation of public international law" has been held by the Appellate Body to refer to Articles 31 and 32 of the Vienna Convention, whose provisions become a source of law insofar as they reflect customary international law. ${ }^{71}$ Other provisions of the Vienna Convention may also provide law in WTO proceedings. For example, a recent panel considered Article 28 on nonretroactivity of treaties before concluding that it did not apply to the facts of the case. ${ }^{72}$ Parties have also cited other articles of the Convention to panels, including Articles 18 (Obligation not to defeat the object and purpose of a treaty prior to its entry into force), 26 (Pacta sunt servanda: "Every treaty in force is binding upon the parties to it and must be performed by them in good faith"), and 30 (Application of successive treaties relating to the same subject matter), although the panels have not yet found it necessary to address them. ${ }^{73}$

An as yet unresolved question is whether the rights and obligations brought into the WTO by these other agreements are only those that were in effect at the time the WTO Agreements became effective, or whether the WTO rights and obligations change as these agreements change. Footnote 2 to the TRIPS Agreement states that references to the intellectual property conventions are to specific versions of those conventions. ${ }^{74}$

\footnotetext{
${ }^{69}$ Agreement on Trade-Related Aspects of Intellectual Property Rights, in FinAL ACT, supra note 2, Art. I.3 [hereinafter TRIPS].

${ }^{70}$ Agreement on Subsidies and Countervailing Measures, in Final ACT, supra note 2, Annex I(k):

[I]f a Member is a party to an international undertaking on official export credits to which at least twelve original Members to this Agreement are parties as of 1 January 1979 (or a successor undertaking which has been adopted by those original Members), or if in practice a Member applies the interest rates provisions of the relevant undertaking, an export credit practice which is in conformity with those provisions shall not be considered an export subsidy prohibited by this Agreement.
}

The "international undertaking" described is the "OECD Arrangement," OECD Doc. OCDE/GD(92)95 (1992).

${ }^{71}$ United States-Standards for Reformulated and Conventional Gasoline, supra note 53, at 17. The Vienna Convention opens the way to the potential relevancy of other international agreements that otherwise may have no direct connection with the WTO Agreements. See the section "Customs," supra.

${ }^{72}$ EC-Measures Concerning Meat and Meat Products (Hormones), Complaint by the United States, supra note 55, paras. 8.24, 8.21; Complaint by Canada, supra note 55, paras. 8.27, 8.28.

${ }^{73}$ See, e.g., Brazil-Measures Affecting Desiccated Coconut, WTO Doc. WT/DS22/R, paras. 23-36, 37-39 (Oct. 17, 1996); U.S. Cotton-Panel Report, supra note 34, paras. 5.224, 7.63.

${ }^{74}$ For example, the text of footnote 2 to the TRIPS Agreement, supra note 69, specifies in part: "In this Agreement, 'Paris Convention' refers to the Paris Convention for the Protection of Industrial Property: 'Paris Convention (1967)' refers to the Stockholm Act of this Convention of 14 July 1967." 
Presumably, therefore, any rights and obligations negotiated later by the parties to the intellectual property conventions would not affect WTO rights and obligations and thus would not be sources of WTO law. However, a panel established under the North American Free Trade Agreement, in considering a provision of NAFTA preserving the rights of the parties under GATT and agreements negotiated under GATT, concluded that the reference at issue was not simply to GATT as it existed when the NAFTA provision came into effect, but to the GATT regime as it had evolved, eventually, into the WTO. ${ }^{75}$ The NAFTA panel also noted that a reference in that Agreement to customary international law was "a reference to an evolving system." "76

Agreements between the parties. The WTO Agreement, and its annexed covered agreements, are among the many international regulatory agreements entered into by governments, particularly in the post-World War II era, to address economic, environmental and social problems. ${ }^{77}$ Many WTO members are parties to most of these agreements. Moreover, it seems likely that the number of regulatory agreements is likely to grow, particularly in the environmental field. This raises the question of the extent to which these agreements affect the rights and obligations of WTO members vis-à-vis other WTO members.

The issue began to appear in the early 1990s. One instance involved not a multilateral treaty, but a bilateral agreement between Canada and the European Community. In connection with negotiations in the early 1960s concerning Canada's exports of wheat to the Community under the Common Agricultural Policy, the parties entered into an agreement that would have extended the time limits within which Canada could challenge the Community's treatment of its wheat exports under Article XXVIII of GATT. Before an arbitrator agreed to by the parties to resolve a dispute as to whether Canada's Article XXVIII complaint had been made too late, the Community challenged Canada's right to bring a claim based on a bilateral agreement under the multilateral procedures of GATT. The arbitrator disagreed:

In principle a claim based on a bilateral agreement cannot be brought under the multilateral dispute settlement procedures of the GATT. An exception is warranted in this case given the close connection of this particular bilateral agreement with the GATT, the fact that the Agreement is consistent with the objectives of the GATT, and that both parties joined in requesting recourse to the GATT Arbitration procedures. ${ }^{78}$

A similar issue arose in a WTO panel's consideration of a recent dispute between Brazil and the Community involving exports of poultry products from Brazil to Europe. ${ }^{79}$ Brazil argued that a bilateral agreement between it and the Community (the Oilseeds Agreement) applied to the resolution of the dispute. Although the United States, as third party, argued that the Oilseeds Agreement was not within the terms of reference, the Community did not explicitly object to its consideration by the panel. ${ }^{80}$ Noting that the Oilseeds Agreement had been negotiated within the framework of GATT Article

\footnotetext{
${ }^{75}$ Arbitral Panel Established Pursuant to Article 2008 of the North American Free Trade Agreement, Final Report: In the Matter of Tariffs Applied by Canada to Certain U.S.-Origin Agricultural Products (Dec. 2, 1996).

${ }^{76} I d$., para. 134 .

${ }^{77}$ The apt phrase "international regulatory agreements" is taken from the subtitle of ABRAM CHAYES \& Antonia Handler Chayes, The New Sovereignty: Compliance with International Regulatory AgreeMENTS (1995).

${ }^{78}$ Canada/European Communities Article XXVIII Rights, Award by the Arbitrator, GATT B.I.S.D. (37th Supp.) at 80,84 (1991)

${ }_{79}$ European Communities-Measures Affecting the Importation of Certain Poultry Products, WTO Doc. WT/DS69/R (Mar. 12, 1998).

${ }^{80}$ Id., para. 197.
} 
XXVIII, and citing the Canada/EC Wheat arbitration, the panel decided to consider the Oilseeds Agreement "to the extent relevant to the determination of the EC's obligations under the WTO agreements vis-à-vis Brazil." 81

The first major foray into the field involving a multilateral agreement, United StatesRestrictions on Imports of Tuna, is illustrative of the tendency of GATT panels to disregard public international law when it came to interpreting the General Agreement. ${ }^{82}$ The United States argued in Tuna, inter alia, that the Convention on International Trade in Endangered Species (CITES) and various other bilateral and plurilateral agreements were relevant to the dispute between GATT parties who were parties to those agreements. ${ }^{83}$ After noting, in a tone suggestive of less than wholehearted approval, that "the parties based many of their arguments . . . on environmental and trade treaties," the panel said that "it was first of all necessary to determine the extent to which these treaties were relevant to the interpretation of the text of the General Agreement." 84 The panel concluded that they were not relevant, stating that "the agreements cited by the parties to the dispute were bilateral or plurilateral agreements that were not concluded among the contracting parties to the General Agreement, and that they did not apply to the interpretation of the General Agreement or the application of its provisions." 85

The panel's conclusion that another international treaty would be relevant to the interpretation of a GATT obligation only to the extent that the treaty was accepted by all GATT parties does not appear to be consistent with Article 31(3) $(c)$ of the Vienna Convention, which specifies that "any relevant rules of international law applicable in the relations between the parties" shall be taken into account in resolving disputes between them. ${ }^{86}$ An interpretation of this language to mean only any subsequent agreement among all of the parties to the GATT - and not simply to an agreement among the parties to the dispute-does not seem supportable by the text of Article 31(3)(c). The word "parties," as used in that provision, would seem to refer to the parties to the particular dispute, not to the parties to the multilateral agreement. In any event, the panel's textual emphasis on the word "parties" would itself seem to diminish the relevance of the reasoning of the Tuna report in the WTO, inasmuch as the participants in the WTO are "Members," not "parties" as they were in GATT.

The Tuna panel also rejected the argument that practice under the other agreements could be considered "subsequent practice in the application of the treaty which establishes the agreement of the parties regarding its interpretation," as provided for in Article 31(3) (b) of the Vienna Convention. According to the panel, any such practice would constitute practice under those other agreements, not under GATT. ${ }^{87}$ This interpretation, too, seems excessively narrow, and not justified by the text of the Convention.

In a widely watched recent report involving restrictions imposed by the United States on imports of shrimp from countries not meeting U.S. standards for protecting sea turtles in the shrimping process, all of the parties to the dispute were also parties to CITES. ${ }^{88}$ As in Tuna, the panel found CITES not relevant to the dispute, but on more limited grounds that seem more persuasive than the verbal distinctions concerning

\footnotetext{
${ }^{81} I d$., para. 2.02. The panel also referred to the Banana panel's consideration of the Lomé Convention. See note 9 supra.

${ }^{82}$ United States-Restrictions on Imports of Tuna, GATT Doc. DS29/R (June 16, 1994), 33 ILM 839 (1994).

${ }^{83} I d$., paras. $3.14,3.21-3.34$.

${ }^{84} I d$., para. 5.18

${ }^{85}$ Id., para. 5.19

${ }^{86}$ Vienna Convention on the Law of Treaties, supra note 53, Art. 31(3) (c).

${ }^{87}$ United States-Restrictions on Imports of Tuna, supra note 82, para. 5.19.

${ }^{88}$ United States-Import Prohibition of Certain Shrimp and Shrimp Products, WTO Doc. WT/DS58/R, para. 7.57 (Apr. 6, 1998).
} 
"parties" drawn in Tuna. The United States restricted imports of shrimp, the panel noted, and shrimp are not an endangered species covered by CITES. Turtles are the endangered species, but the United States took no challenged trade action with regard to turtles. Moreover, the United States had itself informed the panel that CITES neither authorized nor prohibited the measures at issue. ${ }^{89}$

The issue of the impact of other international agreements between parties is likely to arise when one WTO member imposes trade sanctions on the exports of another pursuant to an international agreement, to which both are parties and which calls for sanctions. If the action would otherwise be inconsistent with its WTO obligations, the party taking the action might refer to its obligations under the other agreement in support of an argument that the inconsistency is excused by one or more of the exceptions set forth in GATT Article XX, on the theory that the other agreement constitutes a modification of the WTO legal situation of the participating parties. ${ }^{90}$

The Tuna panel raised another point that is highly germane to the issue of the relevance of other agreements between the parties, although it did so in only a limited way. The panel examined whether the cited treaties could be considered to be subsequent agreements between the parties concerning the interpretation of GATT within the meaning of Article 31 of the Vienna Convention on the Law of Treaties; it concluded, not surprisingly, that they could not be so considered ${ }^{91}$ However, the panel did not look to the question whether GATT and the cited treaties could be considered successive treaties relating to the same subject matter within the meaning of Article 30, rather than Article 31 , of the Convention.

Article 30 is likely to be the more relevant provision of the Convention, particularly with regard to international environmental agreements. Article 30(3) specifies that when the disputants are parties to both agreements, the later in time prevails. Article $30(4)(b)$ also specifies that, as between a state party to both treaties and a state party to only one of the treaties, the treaty to which both are parties governs. This would mean that, in the event that a WTO member is a party to an environmental agreement and another member is not a party to that agreement, the environmental agreement would not affect WTO rights and obligations. This result is consistent with the principle pacta tertiis nec nocent nec prasunt: a treaty binds only the contracting parties and neither rights nor duties arise under a treaty for a state not a party.

To the extent that other agreements are relevant to the rights and obligations of WTO members under the covered agreements, the question arises as to who interprets the pertinent provisions of those agreements. As to agreements specifically brought into the WTO, it now seems settled that WTO panels and the Appellate Body interpret their terms for WTO purposes.

In Bananas both the panel and the Appellate Body considered the scope of a waiver of specified obligations granted by the GATT Council and extended by the WTO General Council to the European Community with respect to the Lomé Convention, which required the Community to extend preferential treatment to goods originating in certain African, Caribbean and Pacific countries (ACP).$^{92}$ The substantive question was: What was required by the Lomé Convention? The European Community and the ACP argued that the panel was not competent to answer that question. Rather, they contended, the

${ }^{90}$ On this issue, see Aaditya Mattoo \& Petros C. Mavroidis, Trade, Environment and the WTO: How Real Is the Conflict?, in International Trade Law AND the GATT/WTO Dispute SETtLement System 325 (Ernst-Ulrich Petersmann ed., 1997).

${ }^{91}$ United States - Restrictions on Imports of Tuna, supra note 82, para. 5.19.

${ }^{92}$ European Communities-Regime for the Importation, Sale and Distribution of Bananas, WTO Doc. WT/ DS27/R (May 22, 1997).
} 
panel should defer to the interpretation advanced by the Community and the ACP, which, as parties, were competent to answer it. ${ }^{93}$

The panel disagreed. It noted that the EC and ACP had originally been granted a waiver by the GATT ConTRACTING PARTIES to permit the preferential treatment, and that the waiver had been adopted by the WTO. Clearly, the waiver itself was a WTO agreement, within the competence of a WTO panel. "Since the waiver applies to action 'necessary . . . to provide preferential treatment . . . as required by the relevant provisions of the Fourth Lomé Convention," " the panel said, "we must also determine what preferential treatment is required by the Lomé Convention." ${ }^{94}$ The Appellate Body affirmed, observing, "To determine what is 'required' by the Lomé Convention, we must look first to the text of that Convention and identify provisions of it that are relevant to trade in bananas." 95

Because the waiver had effectively incorporated the Lomé Convention into a WTO agreement, the panel's authority to interpret the waiver, and therefore the Lomé Convention itself, parallels the authority that is likely to be claimed for the agreements explicitly referred to in the covered agreements, such as the intellectual property conventions. The report does not deal with the situation in which the international agreement at issue is not, at least implicitly, a WTO agreement.

\section{CONCLUSION}

The WTO is the product of an international agreement, and that agreement and the agreements annexed to it constitute the basic source of WTO law. The reports of panels and the Appellate Body, however, add a growingly important gloss to those texts. Most WTO disputes will be resolved primarily, if not solely, with reference to the texts and to prior reports, and in this sense the WTO legal system may be thought of as largely self-contained.

But if the WTO legal system is largely self-contained, it is not entirely self-contained. To the contrary, it is an important part of the larger system of public international law, as reflected not only by the interpretive principles that are brought to bear on its texts, which are explicitly those of public international law, but also by its increasing recourse to the other traditional sources of public international law: custom, the teachings of publicists, general principles of law, and other international instruments, particularly those incorporated by reference into the WTO and its agreements.

Public international law has clearly made an important contribution to WTO law. It is not yet clear that the reverse will be true, that other international tribunals will begin to see the WTO, as reflected in its adopted reports, as a source of law. Given the growing quantity and high overall quality of those reports, however, it seems likely that it is only a matter of time before this recognition begins to take place, particularly with regard to evidentiary and procedural issues that could have wider application.

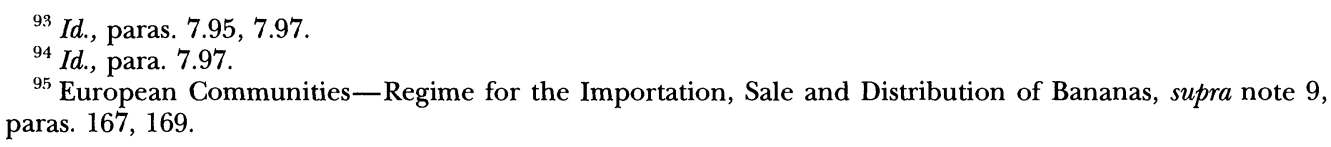

